\author{
Andrei Ionut HUSMAN, PhD Candidate \\ E-mail: husmanandrei12@stud.ase.ro \\ The Bucharest University of Economic Studies \\ Professor Petre BREZEANU, PhD \\ E-mail: petre.brezeanu@fin.ase.ro \\ The Bucharest University of Economic Studies
}

\title{
PROGRESSIVE TAXATION AND ECONOMIC DEVELOPMENT IN EU COUNTRIES. A PANEL DATA APPROACH
}

\begin{abstract}
The types of taxation, the comparisons between them, as well as the implications of taxation on various elements of the economy have been, are and will be topics of interest for the academic environment and among the decision makers. Nevertheless, we further wondered how we could measure the impact of taxation on economic growth, in fact on the well-being of the population. The most relevant indicator in this regard is GDP per capita. But, how can we measure this impact? Our answer to this question is given by an econometric analysis with panel data. Why did we focus on the progressive taxation system? Due to its majority application among EU28 countries. What are our expectations for the results? We expect the results of the econometric analysis to indicate positive direct relations between the tax elements (revenues from direct and indirect taxes) and the economic growth represented by GDP per capita.
\end{abstract}

Keywords: Tax, progressive taxation, economic development, EU countries, panel data, regression models.

\section{JEL Classification: C02, C11, C45, C46, C63}

\section{Introduction}

The increasing globalization and the more pronounced interdependence of the economies create a context in which the subject of taxation occupies a very important place among the decision makers of budgetary and fiscal policy. These policies must target both, the economy as a whole and the particular characteristics. Consequently, these policies should be focused on the impact of certain economic decisions on the population.

The specialized literature shows us that these two policies have a very important role in defining the characteristics of the economic environment and implicitly in ensuring a certain level of development for their own citizens.

Even if the EU member states are in question, this does not require the implementation of an implicit tax system, each Member Stat being in fact free to

DOI: 10.24818/18423264/55.1.21.18 
build its own tax system, but taking into account the tax regulations at EU level, regulations that are seen as guidelines, and do not require the implementation of a specific tax system.

In the case of the EU, the fiscal system is a reflection for the level of demarcation between the market integration and a stronger political union. The EU fiscal system has an important role in the finale of EU market integration and enables a necessary cohesion for maintaining the existing level of EU economic and political integration.

Thus, we observe the existence of this freedom of choice regarding taxation for the EU Member States. However, we further notice that, according to the guidelines/reports issued by $\mathrm{PwC}$ (https://taxsummaries.pwc.com/) and $\mathrm{EY}$ ((http://www.ey.com/gl/en/services/tax/global-tax-guide-archive), the Member States mostly apply a progressive tax system for the income obtained by their citizens. Specifically, 20 of the 28 EU Member States (including the United Kingdom) apply such a tax system, and the list is as follows: Austria, Belgium, Croatia, Cyprus, Denmark, Finland, France, Germany, Greece, Ireland, Italy, Luxembourg, Malta, Netherlands, Poland, Portugal, Slovenia, Spain, Sweden and United Kingdom ("progressive taxation countries").

Most of them are developed countries (from an economic point of view and not only) and this may be a sign that these countries are concerned with ensuring to some extent social equity by progressively taxing citizens' income.

The perspectives from which such a fiscal system can be perceived are multiple and concern various aspect of economic nature, but we will rely on the most important of them, namely we will analyse the perspective from which the tax elements influence the citizens of these countries. Therefore, this perspective combines the main fiscal elements and aims at their impact on the economic growth/economic well-being felt by the citizens. The most conclusive indicator to measure this well-being is represented by GDP per capita.

The fiscal element that occupies the most important role in determining the impact of taxation on the economic well-being of citizens is represented by the personal income tax ("PIT"). Nevertheless, for a precise analysis, the main elements of the nature of direct and indirect taxes must be included. Consequently, as presented in the chapter Research methodology, our analysis includes these main elements.

Thus, our main goal is to achieve a conclusive analysis on the impact of taxation on the economic growth/economic well-being felt at the level of citizens in case of progressive taxation countries.

In order to achieve this goal, our paper includes a chapter that incorporates a relevant extensive analysis of the specialized literature, followed by a chapter that presents the research methodology used in our analysis. In the final chapter are presented and interpreted the results of econometric analysis. 
Progressive Taxation and Economic Development in EU Countries. A Panel Data Approach

\section{Literature review}

Since a tax system has the characteristic of transmitting immediate effects to the economy, the application of a tax system meant to stimulate economic growth, as well as the relationship between taxes and this growth represent and will represent topics of great interest in the literature.

At the same time, the comparison between the two tax systems, progressive and flat, generated numerous studies and analyses. Each of these studies discusses both advantages and disadvantages created by each system, looking at them from various perspectives, such the ones of taxpayers, budget collection, tax burden, equity and equality or of compliance burden. The choice and application of one system to the detriment of the other depends on many elements, taking such a decision must be based on the main economic issues registered by that particular country, such as inequity or the behaviour of taxpayers.

Since our research analyses the progressive tax system, in the following, we will focus mainly on studies on this type of taxation in order to deduce the main advantages and disadvantages revealed in the literature. The aim of the progressive taxation and the benefits of social insurances is to improve the situation of the poorest citizens in a state and to ensure a certain level of fairness. According to Kalyva et al. (2018), an increased level of inequality in terms of income could lead to a significant decrease of economic growth, resulting in a low level of aggregate demand, low investments, low labour productivity and an inefficient allocation of resources. Further, all of these effects have a negative influence on the economy.

The literature shows us in general that the main advantages of the progressive tax are related to a much better fulfilment of the objectives of social justice, to a more equitable distribution of income that leads to a greater wealth of citizens. This fact is analysed, debated and supported by numerous authors.

At the same time, several authors (such as Chen and Guo, 2019) demonstrate that the progressive tax system can act as a stabilizer in the sense that, in times of recession, citizens' income move within lower taxation limits (lower income brackets), while in expansionist periods the situation is reversed. Thus, the progressive nature of taxation leads to a stability of economic growth (expressed by GDP) due to the fact that disposable income is more stable over time, regardless of economic cycles.

In terms of disadvantages, the literature mainly indicates that this tax system leads to a higher tax burden on higher income. In other words, higher income imply higher taxes, this aspect being debated by Husman and Brezeanu (2019) in the case of the Nordic countries, which apply this type of taxation. Furthermore, in the literature, to the two systems are assigned two concepts each, namely, the flat tax system is assigned the concept of equality, and the progressive tax system is assigned the concept of equity. In this regard, Bikas et al. (2014)

DOI: 10.24818/18423264/55.1.21.18 
suggest that the more progressive the taxation, the higher the inequalities in citizens' income and vice versa.

Another disadvantage mentioned in the literature is its complexity caused by several levels of taxation, a complexity that leads to high administrative and compliance costs. Precisely due to this complexity, but also to the fact that the highest tax rates are applied to high income, this system leads to a high tax evasion with adverse effects on economic growth (Godar et al., 2015). Thus, we can observe that various authors challenge the potential of a progressive tax system to help economic growth.

Nevertheless, we can assign a different perspective if we take into account the premises of the Keynesian theory according to which the aggregate demand (private consumption) is directly impacted by the disposable income and further determines the level of general economic activity. In this regard, Godar et al. (2015) debate the negative relationship between the level of income inequality and private consumption and states that a correction performed based on the tools of the tax system on disparity in income distribution can stimulate private consumption and implicitly can stimulate the economic growth. Alternatively, since the multiplier of government expenditure is revealed to be higher than that of government revenue, the increase in state budget revenues (due to progressive taxation) could finance a diversity of government expenditures, which ultimately lead to economic growth.

Through a regression technique, named Reiterative Truncated Projected Least Squares, Leightner and Haiqi (2016) found that a transfer of the tax burden from the socially disadvantaged part of population to the advantaged one would lead to an increase in GDP. Further, in the case of 13 from 23 countries they found that corporate income tax and property taxes better contribute to the increase in GDP than PIT and sales taxes.

We observe that the specialized literature brings us a vast theoretical and empirical argumentation on the advantages and disadvantages of tax systems, but also on the way in which the progressive taxation could influence the development of a country. Furthermore, the authors' attention was also focused on studying the impact that taxation (either progressive or flat) has on the main elements of economies (mainly referring to economic growth), including statistical/econometric analysis.

The analysis of the effects of fiscal elements in the economies of countries can be found in older studies from " 50 s to ' 70 s but several authors could not identify a relationship between tax elements and economic growth.

It was not until the late ' 80 s and early ' 90 s that we found studies in the literature to identify the correlations between tax elements and countries' economic growth. Thus, Helms (1985) found a significant negative impact of state and local taxes on economic growth, while Burgess and Stern (1993) found a certain correlation between the tax rates and GDP per capita only in the case of developing countries. 
Progressive Taxation and Economic Development in EU Countries. A Panel Data Approach

In the recent periods, several authors analysed and found certain correlations (whether positive or negative) between tax elements and economic growth/other economic elements.

In his study, Widmalm (2001) used pooled cross-sectional data and found at the level of 23 OECD countries that in the period 1965-1990 the PIT has a negative effect on the economic growth. In addition, certain empirical evidence was found by this author on the fact that tax progressivity is associated with a low level of economic growth. Padovano and Galli (2002) obtained similar results. More specifically, they used a panel of 25 industrialized countries for the period 1970-1998 and they obtained a negative effect of effective marginal tax rates and tax progressivity on economic growth.

However, the literature shows that some studies have obtained quite different results regarding the analysed cause (as we also see in the case of studies that are more recent). Therefore, in a Vector Autoregressive Regression approach, De Castro and de Cos (2008) highlighted that an increase in taxes generates irrelevant positive effects on the GDP, but a negative effects on medium term. In a similar approach, but using the Vector Stochastic Process with Dummy Variables, Kuismanen and Kämppi (2010) analysed the effects of fiscal policy decisions on the economy in the case of Finland. They concluded that an increase in public sector revenues could have positive effects on investment and GDP and they correlate these results with a good economic era, as increased taxes would lead to an increased activity in private sector and both being caused by this good economic era. Through a certain linear regression with panel-corrected standard errors, Dolenc \& Laporsek (2010) found a negative relationship between PIT and employment growth.

In the specific case of Romania, Mutaşcu and Dănuleţiu (2011) used a Vector Autoregressive model (VAR) and they found that, in the long term, a positive shock in the rate of dynamic taxation's level generates an increase in the level of economic growth. Through a similar methodology, Bazgan (2018) found that a positive change in the structure of indirect taxes could have a strong positive effect on the economic growth on a medium-term period, while a positive change in the structure of direct taxes will have a negative impact on short-term, then returning to a positive impact. Surugiu and Surugiu (2018) used the classification of revenues in distortionary taxes, non-distortionary taxes and other taxes. Through a regression model, they found a negative impact of distortionary taxes on economic growth, while the non-distortionary taxes have a positive impact. However, in a subsequent similar analysis of Surugiu and Surugiu (2018) used only the direct taxes (CIT and PIT) and indirect taxes (VAT) and found that both variables have a significant positive impact on the economic growth for in the period 1995-2014.

By the means of the regression analysis, Stoilova \& Patonov (2012) found a significant positive effect of PIT and social security contributions ("SSC") on the long-term economic growth in the case of EU countries.

DOI: 10.24818/18423264/55.1.21.18 
Vatavu et al. (2019) used a Granger causality analysis and found that taxes support economic growth. Moreover, Piketty et al. (2011) found that top tax rates on personal income are positively associated with economic growth in the case of certain OECD countries. Similarly, Milasi and Waldmann (2017) found a positive linear relationship between top marginal tax rates and GDP growth over the period 1980-2009 at the level of 18 OECD countries. Similar results were also obtained by Andrašić et al. (2019).

The closest study as a structure with ours is the one conducted by Elshani \& Ahmeti (2017) at the level of twenty European OECD countries that apply a progressive taxation system for the period 2002-2014. They used a panel data regression in order to study the impact of taxation on economic growth. Their results indicated that PIT has a negative impact on GPD per capita (a proxy for economic growth), while CIT and VAT have a strong positive impact on GDP per capita.

As presented above, a wide range of studies on the impact of taxation is offered by the literature, including numerous studies using econometric instruments.

\section{Research methodology}

As used by various authors (Surugiu and Surugiu, 2018; Elshani and Ahmeti, 2017 and Andrašić et al., 2019), in order to analyse the impact of taxation on economic growth, we focused on the approach of Barro and Sala-i-Martin (2004) and we underline the impact of each tax and not at an aggregate level.

We carried out econometric analyses based on panel data and through Stata software. We have included the main revenues from taxes as presented below

Our analysis started from the equation of the following model:

$$
\begin{aligned}
& G D P p c_{-} p_{i t}=\beta_{0}+\beta_{1} \times C I T_{-} p_{i t}+\beta_{2} \times P I T_{-} p_{i t}+\beta_{3} \times V A T_{-} p_{i t}+ \\
& \beta_{4} \times S S C_{-} p_{i t}+u_{i t}
\end{aligned}
$$

Where:

- GDPpc $\_$p $=$the Gross domestic product per capita expressed as growth percentages from previous year;

- CIT_p = the Corporate income tax expressed as growth percentages year by year;

- $\quad$ PIT_p $=$ the Personal income tax expressed as growth percentages year by year;

- VAT_p = the Value added tax expressed as growth percentages year by year; 
Progressive Taxation and Economic Development in EU Countries. A Panel Data Approach

- $\quad$ SSC_p $=$ the Social security contributions expressed as growth percentages year by year;

- $\beta 0=$ the constant;

- $\quad \beta 1-\beta 4=$ the coefficients for each independent variable;

- $\mathrm{u}=$ the error term;

- $\mathrm{i}=$ the country;

- $\mathrm{t}=$ the time (year).

The period analysed was 2003-2018 and the data were extracted from Eurostat database (https://ec.europa.eu/eurostat/data/database).

Further, as stated above, based on the guidelines/reports issued by $\mathrm{PwC}$ (https://taxsummaries.pwc.com/) and EY

(http://www.ey.com/gl/en/services/tax/global-tax-guide-archive), we established the countries subject to the econometric analysis. Therefore, the following 2028

EU Member States were included in the analysis: Austria, Belgium, Croatia, Cyprus, Denmark, Finland, France, Germany, Greece, Ireland, Italy, Luxembourg, Malta, Netherlands, Poland, Portugal, Slovenia, Spain, Sweden and United Kingdom.

\section{Econometric results}

Starting from the methodology mentioned in the chapter Research methodology, we went through several steps in our econometric analysis to reach a robust, viable and statistically significant econometric model. In the following, we will present these steps.

\section{The fixed effect model}

Our analysis started by performing certain tests in order to decide which type of regression we shall use. According to these tests, the individual effects were found as not negligible. Therefore, our decision was to use a panel data regression model with fixed effects ("FE model"). In order to estimate this model, we used the function $x$ treg from Stata and the results is presented in Table 1 below.

Table 1. The first FE model output

\begin{tabular}{|c|c|}
\hline xtreg GDPpc_p $C I T \_p P I T$ & \\
\hline Fixed-effects (within) regre & \\
\hline Group variable: country & Number of obs $=312$ \\
\hline R-square overall $=0.6152$ & Number of groups $=20$ \\
\hline & Obs per group: \\
\hline $\mathrm{F}(4,288)=114.2$ & $\min =8$ \\
\hline
\end{tabular}

DOI: 10.24818/18423264/55.1.21.18 
Andrei Ionut Husman, Petre Brezeanu

\begin{tabular}{|c|c|c|c|c|c|c|}
\hline \multicolumn{7}{|c|}{$x t r e g G D P p c \_p C I T \_p P I T \_p V A T \_p S S C \_p, f e$} \\
\hline \multicolumn{4}{|c|}{ Prob $>F=0.0000$} & \multicolumn{3}{|c|}{$\max =16$} \\
\hline GDPpc_p & Coef. & Std. Err. & $\mathrm{t}$ & $\mathrm{P}>|\mathrm{t}|$ & \multicolumn{2}{|c|}{ [95\% Conf. Interval] } \\
\hline CIT_p & 0.0869238 & 0.0115969 & 7.50 & 0.000 & 0.0640983 & 0.1097493 \\
\hline PIT_p & 0.1254704 & 0.0238863 & 5.25 & 0.000 & 0.0784566 & 0.1724841 \\
\hline VAT_p & 0.2219858 & 0.0289782 & 7.66 & 0.000 & 0.1649498 & 0.2790218 \\
\hline SSC_p & 0.1527755 & 0.0269277 & 5.67 & 0.000 & 0.0997754 & 0.2057756 \\
\hline _cons & 0.0045520 & 0.0020574 & 2.21 & 0.028 & 0.0005025 & 0.0086015 \\
\hline
\end{tabular}

Source: own processing in Stata

The output shows us that the value of Prob (F) is greater than 0.05 (5\%), which indicates that all the coefficients in this model are different from zero. Further, the R-square register values of over $0.5(50 \%)$. Given these, we can assume that the model is valid as a whole from a statistical point of view.

All the independent variables have a significant statistical influence on the GDP per capita, since the p-value for all these variables is greater than $0.05(5 \%)$. Such significance is also reinforced by the t-values that are all greater than 1.96.

\section{The random effects model}

In the following step, based on the same data, we estimate the random effect model ("RE model") by using the same function, xtreg. The output of this model is presented in the Table 2 below. The results obtained by estimating the RE model are similar to the one obtained in the case of FE model and the same mentioned on the statistical significance are valid.

Table 2. The RE model output

\begin{tabular}{|c|c|c|c|c|c|c|}
\hline \multicolumn{7}{|c|}{$\begin{array}{l}x \text { treg } G D P p c_{\_} p C I T \_p P I T \_p V A T \\
\text { Fixed-effects (within) regression }\end{array}$} \\
\hline \multicolumn{4}{|c|}{ Group variable: country } & \multicolumn{3}{|c|}{ Number of obs $=312$} \\
\hline \multicolumn{4}{|c|}{ R-square overall $=0.6153$} & \multicolumn{3}{|c|}{ Number of groups $=20$} \\
\hline & & & & \multicolumn{3}{|c|}{ Obs per group: } \\
\hline \multicolumn{4}{|c|}{ Wald chi2 $(3)=491.12$} & \multicolumn{3}{|c|}{$\min =8$} \\
\hline \multicolumn{4}{|c|}{ Prob $>F=0.0000$} & \multicolumn{3}{|c|}{$\max =16$} \\
\hline GDPpc_p & Coef. & Std. Err. & $\mathrm{t}$ & $\mathrm{P}>|\mathrm{t}|$ & \multicolumn{2}{|c|}{ [95\% Conf. Interval] } \\
\hline CIT_p & 0.0902846 & 0.0114771 & 7.87 & 0.000 & 0.0677899 & 0.1127793 \\
\hline
\end{tabular}


Progressive Taxation and Economic Development in EU Countries. A Panel Data Approach

\begin{tabular}{|l|l|l|l|l|l|l|}
\hline \hline$x$ treg $G D P p \_p C I T \_p$ & $P T \_p$ VAT_p SSC_p,re \\
\hline PIT_p & 0.1282033 & 0.0235352 & 5.45 & 0.000 & 0.0820751 & 0.1743315 \\
\hline VAT_p & 0.2156125 & 0.0285086 & 7.56 & 0.000 & 0.1597365 & 0.2714884 \\
\hline SSC_p & 0.1546702 & 0.0263545 & 5.87 & 0.000 & 0.1030164 & 0.2063239 \\
\hline cons & 0.0044666 & 0.0020346 & 2.20 & 0.028 & 0.0004789 & 0.0084542 \\
\hline
\end{tabular}

Source: own processing in Stata

\section{Choosing the model: FE model or RE model?}

According to Baltagi (2005), in order to decide which model is more suitable, the Hausman test should be performed. In this respect, by running this test in Stata we obtained the results presented in Table 3 below. The output present an associated probability of the Hausman test of over 0.05, showing us (at a first glance) that the RE model would be more suitable. Nevertheless, as stated by Baltagi (2005), the result of Hausman test should be linked with the economic environment and with other tests. Therefore, we proceed to run the Breusch and Pagan Lagrangian multiplier test in Stata by using the function $x t t e s t 0$. The scope was to verify if the null hypothesis that implies the RE model is not appropriate.

Table 3. The output of Hausman test

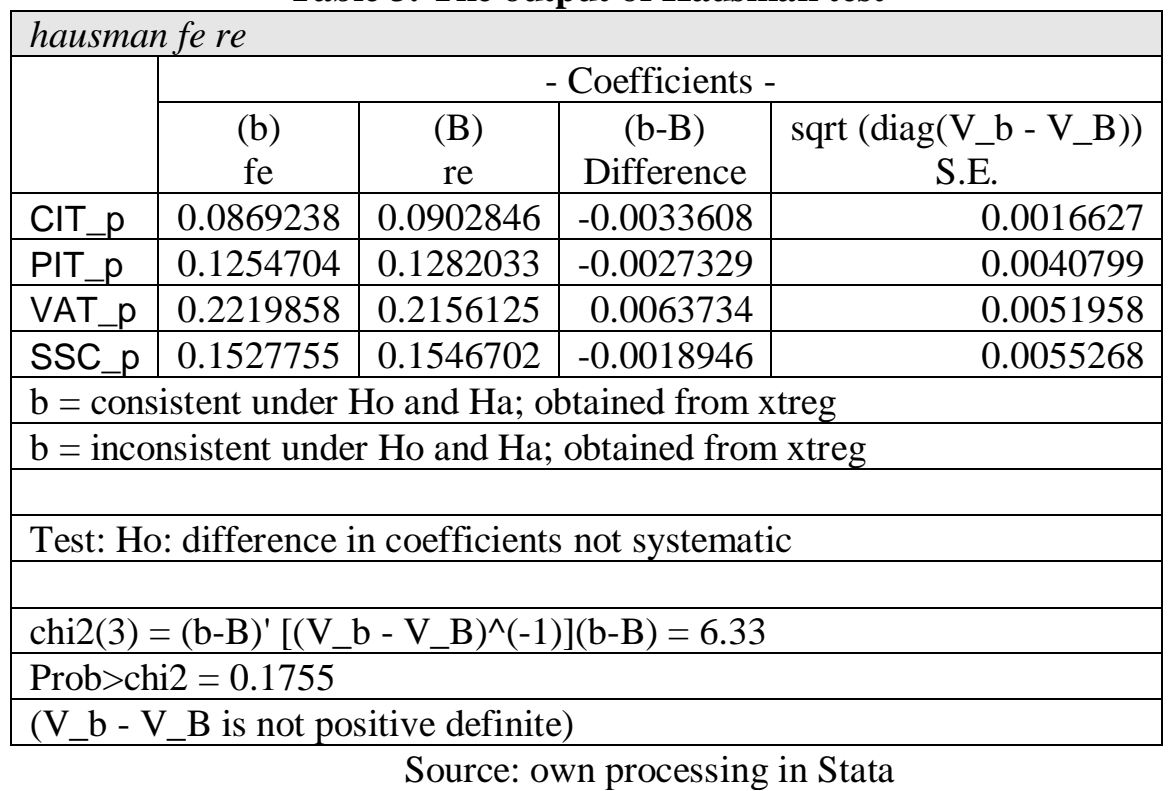

We failed to reject the null hypothesis due to the associated probability of the test which is greater than 0.05 , noting that the RE model is not appropriate. Consequently, taking also in consideration that the observations included are not a

DOI: $10.24818 / 18423264 / 55.1 .21 .18$ 
sample from a pool data, we continue the econometric tests on FE model, having the goal to establish a reliable model.

\section{Testing for heteroskedasticity}

We continue the statistical tests with measuring the variance of the residual variable, which should be constant over time. Therefore, we tested the heteroskedasticity hypothesis by using the Modified Wald test for groupwise heteroscedasticity. Based on xttest 3 command in Stata, we run the test and the result is presented in Table 4 below.

\section{Table 4. The output of Breusch and Pagan Lagrangian multiplier test for} random effects

\begin{tabular}{|c|c|c|}
\hline \multicolumn{3}{|l|}{ xttest0 } \\
\hline \multicolumn{3}{|c|}{ Breusch and Pagan Lagrangian multiplier test for random effects } \\
\hline \multicolumn{3}{|c|}{ GDPpc_p $[$ country,t $]=\mathrm{Xb}+\mathrm{u}[$ country $]+\mathrm{e}[$ country, $\mathrm{t}]$} \\
\hline \multicolumn{3}{|c|}{ Estimated results: } \\
\hline & Var & $\mathrm{sd}=\operatorname{sqrt}($ Var $)$ \\
\hline GDPpc_p & 0.0022675 & 0.0476185 \\
\hline $\mathrm{e}$ & 0.0008821 & 0.0297 \\
\hline $\mathrm{u}$ & 0 & 0 \\
\hline \multicolumn{3}{|c|}{ Test: $\operatorname{Var}(\mathrm{u})=0$} \\
\hline \multicolumn{3}{|c|}{ chibar2 $(01)=0.00$} \\
\hline \multicolumn{3}{|c|}{ Prob $>$ chibar $2=1.0000$} \\
\hline
\end{tabular}

Source: own processing in Stata

According to this output, the probability of this test is under $0.05(5 \%)$ and the null hypothesis according to which the errors are homoscedastic should be rejected and there is heteroscedasticity.

\section{Testing for cross-sectional independence}

Further, we run the Pesaran's test of independence in order to test if the residuals are correlated across countries. By using the command $x t c s d$ we obtained the output presented in Table 5 below.

Table 5. The output of Pesaran's test of cross sectional independence

\begin{tabular}{|l|}
\hline$x t c s d$, pesaran abs \\
\hline Pesaran's test of cross sectional independence $=4.242, \operatorname{Pr}=0.0000$ \\
\hline Average absolute value of the off-diagonal elements $=0.259$ \\
Source: own processing in Stata
\end{tabular}


Progressive Taxation and Economic Development in EU Countries. A Panel Data Approach

The null hypothesis of this test states that the residuals are not correlated across countries. Given the probability obtained of 0.259 , we failed to reject the null hypothesis and there is no cross-sectional dependence.

\section{$\underline{\text { Testing for serial correlation }}$}

According to the null hypothesis of Wooldridge test, there is no serial correlation in panel data. By running the command xtserial, we obtained the output presented in Table 6 below. Given the probability of 0.3610, we conclude that the data used does not present first-order autocorrelation.

Table 6. The output of Wooldridge test for autocorrelation in panel data

\begin{tabular}{|l|}
\hline$x t s e r i a l ~ G D P p c \_p C I T \_p P I T \_p V A T \_p S S C \_p$ \\
\hline Wooldridge test for autocorrelation in panel data \\
\hline Ho: no first-order autocorrelation \\
\hline $\mathrm{F}(1,19)=0.876$ \\
\hline Prob $>\mathrm{F}=0.3610$ \\
Source: own processing in Stata
\end{tabular}

\section{$\underline{\text { Testing for data stationarity }}$}

Our analysis contained also tests for unit roots/stationary within the set of panel data used obtained by running the command xtunitroot in Stata, which results in an output of the Levin-Lin-Chu unit-root test. We rejected the null hypothesis in all the cases due to p-values that are lower than 0.05 threshold and we conclude that all the variables are stationary.

\section{The final fixed effect model}

Taking into account the statistical tests carried out, we proceeded to estimate a fixed effects model by using the command $x t s c c$ in Stata. This estimate is robust to disturbances as heteroscedasticity, autocorrelation of errors and crosssectional dependence. Consequently, these results are more reliable from an econometric point of view. The output of the final fixed effect model is presented in Table 7 below.

DOI: $10.24818 / 18423264 / 55.1 .21 .18$ 
Table 7. The final FE model output

\begin{tabular}{|c|c|c|c|c|c|c|}
\hline \multicolumn{4}{|c|}{$\begin{array}{l}\text { Regression with Driscoll-Kraay standard } \\
\text { errors }\end{array}$} & \multicolumn{3}{|c|}{ Number of obs $=312$} \\
\hline \multicolumn{4}{|c|}{ Method: Fixed-effects regression } & \multicolumn{3}{|c|}{ Number of groups $=20$} \\
\hline \multicolumn{4}{|c|}{ Group variable (i): country } & \multicolumn{3}{|c|}{$\mathrm{F}(4,15)=393.15$} \\
\hline \multirow{2}{*}{\multicolumn{4}{|c|}{ maximum lag: 2}} & \multicolumn{3}{|c|}{ Prob $>F=0.0000$} \\
\hline & & & & \multicolumn{3}{|c|}{ within R-squared $=0.6133$} \\
\hline \multicolumn{7}{|c|}{\begin{tabular}{l|l|l|l|l|l} 
GDPpc_p & Coef. & Std. Err. & $\mathrm{t}$ & $\mathrm{P}>|\mathrm{t}|$ & [95\% Conf. Interval] \\
\end{tabular}} \\
\hline CIT_p & 0.0869238 & 0.018404 & 4.72 & 0.000 & 0.0476966 & 0.1261511 \\
\hline PIT_p & 0.1254704 & 0.0358116 & 3.50 & 0.000 & 0.0491398 & 0.2018009 \\
\hline VAT_p & 0.2219858 & 0.029344 & 7.56 & 0.000 & 0.1594407 & 0.234531 \\
\hline SSC_p & 0.1527755 & 0.0475152 & 3.22 & 0.006 & 0.0514993 & 0.2540518 \\
\hline cons & 0.004552 & 0.0022634 & 2.01 & 0.063 & -0.0002723 & 0.0093763 \\
\hline
\end{tabular}

Source: own processing in Stata

The results obtained in the robust model are similar to the results in the first model estimated, but there are better p-values and t-values. From a statistical perspective, the model is considered valid, all the independent variables having a significant influence on the dependent variable.

We found positive direct relationships between the tax elements included and the GDP per capita in all cases.

Our econometric analysis was carried out based on the methodologies stated by Baltagi (2005) and Wooldridge (2010).

In terms of economic interpretation, the results indicate the following:

- CIT impact: One percentage point increase in CIT revenues leads to an increase in GDP by 0.08 percentage points, given that the other independent variables remain constant. The small value of this coefficient (in comparison with the other ones) can show us that the corporate taxation does not have such a pronounced effect on the GDP per capita (as proxy for the economic wealth felt at the citizens' level).

- PIT impact: One percentage point increase in PIT revenues leads to an increase in GDP by 0.12 percentage points, given that the other independent variables remain constant. The most important element from our analysis registered the second highest value of the coefficient among the independent variables included in the model. Such coefficient can be perceived in the light of the fact that once the taxes levied on citizens are higher and their income is higher. As a result, the economic growth felt at

DOI: $10.24818 / 18423264 / 55.1 .21 .18$ 
Progressive Taxation and Economic Development in EU Countries. A Panel Data Approach

the level of citizens is increased. Another view on this coefficient can show us that PIT is less harmful to economic wealth.

- VAT impact: One percentage point increase in VAT revenues leads to an increase in GDP by 0.22 percentage points, given that the other independent variables remain constant. The highest value of the coefficient, among all the other elements, obtained for VAT is explained by the consumption-based economies of the analysed countries. Thus, we can conclude that consumption leads to economic wealth, which is easy to understand from an economic perspective.

- SSC impact: One percentage point increase in SSC revenues leads to an increase in GDP by 0.15 percentage points, given that the other independent variables remain constant. The economic explanation of this coefficient goes in the same direction as that of PIT. However, this rather high coefficient may show the social nature of these tax systems.

Our results follow to some extend the last trend observed in the literature. Thus, our study represents a contribution to the specialized literature with a specific analysis and conclusive economic and statistic results.

\section{Conclusions}

This paper investigated the impact of the main elements of the tax revenue on the economic growth felt at the level of citizens in the case of EU Member States that apply a progressive taxation system.

We have obtained a robust econometric model with fixed effects that uses panel data for period 2003-2018. The results showed a positive direct relationship between all the tax elements and the GDP per capita (as a proxy for the economic growth).

The positive relationship can bring us arguments to support the statement according to which the progressive tax system ensures a social equity. Implicitly, this system ensures to a certain extent an economic development/economic wellbeing for the citizens of such countries, a fact that is affirmed and supported by various authors (Godar et al., 2015).

Furthermore, given that the analysed period includes both recessionary periods (2008 crisis) and expansionist periods, one can argue that, based on the econometric results, Keynesian theory was validated by the progressive taxation system applied at the country level. EU28, and this system managed to stabilize the economy through its mechanisms (Chen and Guo, 2019)

We find the results to be similar to those of Wojciechowska-Toruńska (2017) that stated that through promoting higher taxation with higher tax progressivity may lead to higher levels of economic growth. Further, based on our results we can affirm that taxes are closely related to well-being (Vatavu et al., 2019).

DOI: $10.24818 / 18423264 / 55.1 .21 .18$ 
In terms of econometric analysis, by using the approach of Barro and Salai-Martin (2004) on the tax elements included in our panel regression model, we found our results in agreement with those obtained on a particular country by Mutaşcu and Dănuleţiu (2011) or Surugiu and Surugiu (2018). Further, in order to extend the application, similar results were found at the level of EU by Stoilova \& Patonov (2012) and at the level of Central and Eastern Europe countries and the developed European Countries by Vatavu et al. (2019).

We note that our results are not entirely similar to those obtained by Elshani and Ahmeti (2017) in the case of OECD countries that apply this tax system. Specifically, our results indicate a positive relationship between PIT and GDP per capita, while Elshani and Ahmeti (2017) found a negative relationship between PIT and GDP per capita. This difference can be explained by the specifics of the countries and the analysed period (2002-2014). However, the positive relationship between PIT and GDP is verified with the results obtained by Andrašić et al. (2019) at the level of 35 OECD countries. In addition, compared to the econometric results obtained by Andrašić et al. (2019), in our analysis, the impact of PIT is statistically significant.

Our results are to some extent consistent with the literature, and our study makes a contribution to the literature through a better understanding of the relationship between the elements of taxation and economic growth at a specific level, namely at the level of countries that apply progressive taxation.

\section{REFERENCES}

[1] Andrašić, J., Kalaš, B., Mirović, V., Milenković, N., Pjanić, M. (2018), Econometric Modelling of Tax Impact on Economic Growth: Panel Evidence from OECD Countries. Economic Computation \& Economic Cybernetics Studies \& Research, 52(4); ASE Publishing;

[2] Baltagi, B.H. (2005), Econometric Analysis of Panel Data. 3rd edition. John Wiley\&Sons Ltd.;

[3] Barro, R. J., Sala-i-Martin, M. (2004), Economic Growth. 2nd edition. The MIT Press;

[4] Bazgan, R. M. (2018), The Impact of Direct and Indirect Taxes on Economic Growth: An Empirical Analysis Related to Romania. Proceedings of the 12th International Conference on Business Excellence 2018, 114-127;

[5] Bikas, E., Subaciene, R., Astrauskaitė, I., Keliuotytė-Staniulėnienė, G. (2014), Evaluation of the Personal Income Progressive Taxation and the Size of Tax-Exempt Amount in Lithuania. Ekonomika 2014, 93, 84-101;

[6] Burgess, R., Stern, N. (1993), Taxation and Development. Journal of Economic Literature, 31(2), 762-830;

[7] Chen, S. H., Guo, J. T. (2019), Progressive Taxation as an Automatic

Destabilizer under Endogenous Growth. Journal of Economics, 127(1), 47-71; 
Progressive Taxation and Economic Development in EU Countries. A Panel Data Approach

[8] De Castro Fernandez F., Herandez de Cos P. (2008), The Economic Effects of Fiscal Policy. The Case of Spain. Journal of Macroeconomics, vol. 30, issue. 3, September;

[9] Elshani, A., Ahmeti, S. (2017), The Effect of Progressive Tax on Economic Growth: Empirical Evidence from European OECD Countries. International Journal of Economic Perspectives, vol. 11, issue 4, 18-25;

[10] Godar, S. Paetz, C. Truger, A. (2015), The Scope for Progressive Tax Reform in the OECD Countries. A Macroeconomic Perspective with a Case Study for Germany. Rev. De l'OFCE 2015, 5, 79-117;

[11] Helms, L. J. (1985), The Effect of State and Local Taxes on Economic Growth: A Time Series Cross-Section Approach. The Review of Economics and Statistics, 67, 574-82;

[12] Husman, A. I., Brezeanu, P. (2019), The Nordic Countries and their Tax Systems. Higher Taxes, Higher Wealth? 5th International Conference - ERAZ 2019 - Knowledge Based Sustainable Development, Budapest - Hungary, May 23, 2019, Selected Papers;

[13] Leightner, J. E., Haiqi, Z. (2016), Tax Policy, Social Inequality and Growth. Contemporary Social Science, 11(2-3), 253-269;

[14] Kalyva, A., Prince, S., Leodolter, A., Astarita, C. (2018), Labour Taxation and Inclusive Growth. (No. 084). Directorate General Economic and Financial Affairs (DG ECFIN), European Commission;

[15] Kuismanen, M., Kamppi, V. (2010), The Effects of Fiscal Policy on Economic Activity in Finland. Economic Modelling, 27;

[16] Mutaşcu, M. I., Dănuleţiu, D. C. (2011), Taxes and Economic Growth in Romania. A VAR Approach. Annales Universitatis Apulensis-Series Oeconomica, 13(1);

[17] Padovano, F., Galli, E. (2001), Tax Rates and Economic Growth in the OECD Countries. Economic Inquiry, 39(1), 44-57;

[18] Piketty, T., Saez, E., Stantcheva, S. (2014), Optimal Taxation of Top Labor Incomes: A Tale of Three Elasticities. American economic journal: economic policy, 6(1), 230-71;

[19] Milasi, S., Waldmann, R. J. (2018), Top Marginal Taxation and Economic Growth. Applied Economics, 50(19), 2156-2170;

[20] Stoilova, D., Patonov, N. (2012), An Empirical Evidence for the Impact of Taxation on Economy Growth in the European Union. Book of ProceedingTourism and Management Studies International Conference Algarve, Vol. 3. ESGT University of the Algarve, Portugal;

[21] Surugiu, M.R., Surugiu, C. (2018), The Assessment of Taxation Impact on Economic Development. A Case Study of Romania (1995-2014). EuroEconomica - Business Administration and Business Economics, 2(36)/2017, 7-20;

[22] Vatavu, S., Lobont, O. R., Stefea, P., Brindescu-Olariu, D. (2019), How Taxes Relate to Potential Welfare Gain and Appreciable Economic Growth. Sustainability, 11(15), 4094;

DOI: 10.24818/18423264/55.1.21.18 
Andrei Ionut Husman, Petre Brezeanu

[23] Widmalm, F. (2001), Tax Structure and Growth: Are Some Taxes Better than Others?. Public Choice, 107(3-4), 199-219;

[24] Wojciechowska-Toruńska, I. (2017), Tax Progression vs. Economic Growth \& Development Index (GDI). Annales Universitatis Mariae CurieSkłodowska, Sectio H Oeconomia, 51(5), 331-338;

[25] Wooldridge, J. M, (2010), Econometric Analysis of Cross Section and Panel Data. MIT press. 